\title{
FEMINISMO DE BASE COMUNITÁRIA NO CONJUNTO DE FAVELAS DA MARÉ (RJ): UMA ANÁLISE DE INICIATIVAS QUE DISCUTEM QUESTÕES DE GÊNERO
}

\author{
COMMUNITY BASED FEMINISM: INITIATIVES THAT DISCUSS \\ GENDER IN MARÉ (RJ)
}

Patricia Elisa Rivera ${ }^{1}$

\begin{abstract}
RESUMO
O presente artigo objetiva refletir sobre as pedagogias feministas de base comunitária produzidas por 4 iniciativas que promovem debates sobre gênero no contexto do conjunto de favelas da Maré. $\mathrm{O}$ estudo partiu de uma abordagem qualitativa empreendendo o cruzamento de observações participantes, entrevistas e estudos bibliográficos para investigar os saberes e as práticas produzidos por estas mulheres e avaliar em que medidas tais ações se aproximam das diferentes vertentes feministas, da educação popular e de uma perspectiva decolonial. Neste artigo, serão apresentados alguns dos resultados das entrevistas realizadas com 17 mulheres no ano 2016. Assim, as experiências analisadas focam nas perspectivas de mulheres dos distintos territórios das periferias da América Latina, de mulheres que resistem em contextos de violências e que, em meio a esses contextos, constroem espaços e produzem pedagogias que desconstroem e descolonizam modos de pensar e transformam as formas de agir.
\end{abstract}

Palavras-chave: Pedagogias decoloniais; feminismo de base comunitária; violência de gênero (VDG); violência contra a mulher (VCM).

\begin{abstract}
This article aims to reflect upon community based feminist pedagogies produced by 4 initiatives that promote debates on gender issues in the context of the favelas of Maré, Rio de Janeiro. The study used a mix of qualitative research methods including participant observation, semi-structured interviews, and a bibliographic review to investigate the knowledge and practices produced by these women. Furthermore, a focus of the study was to evaluate to what measure such actions, practices incorporate different feminist, popular education, and decolonial perspectives. In this article some of the results attained through interviews held in 2016, with 17 women from the initiatives studied, will be presented. The experiences studied in this research focus on the perspectives of women from distinct territories, living in the peripheries of urban centers in Latin America, women who resist in contexts of violence and who, in the midst of these contexts, construct spaces, produce pedagogies that deconstruct and decolonize ways of thinking, and subsequently, change gender biased attitudes.
\end{abstract}

Keywords: Decolonial Pedagogies; Community based feminism; Gender Based Violence (GBV); Violence Against Women (VAW).

${ }^{1}$ Graduada em Relações Internacionais pela George Mason University e Doutora em Ciências Socais pela Universidade do Estado do Rio de Janeiro-UERJ. Integrante do Grupo de Pesquisa, Núcleo de Estudos de Desigualdades e Relações de Gênero-NUDERG. E-mail: p.elisarivera@gmail.com 


\section{nevistet \\ Debates Insubmissos}

\section{INTRODUÇÃO}

O presente artigo ${ }^{2}$ reflete sobre as práticas de diferentes iniciativas protagonizadas por mulheres que discutem questões de gênero ${ }^{3}$ em quatro comunidades do conjunto de Favelas da Maré (RJ), identificando em que medidas tais ações se aproximam da teoria decolonial, da educação popular e de diferentes abordagens de feminismo, incluindo, em especial, uma perspectiva de Feminismo de Base Comunitária. Neste caso, entende-se que a concepção de um Feminismo de Base Comunitária compreende os feminismos que emergem dos cotidianos das comunidades, que se constroem a partir das vivências, das experiências, das histórias e trajetórias de vida das sujeitas dos territórios.

Neste trabalho, serão apresentados alguns dos resultados de entrevistas realizadas no ano de 2016, com 17 mulheres envolvidas nestas iniciativas que discutem questões de gênero na Maré. O desejo pessoal de não querer focar na vitimização de mulheres foi prioritário, pois a realidade observada em campo não refletia a vitimização como característica principal. Mas sim, o fato de que, apesar de sofrerem diferentes formas de violência, as mulheres da Maré superam, se organizam e constroem soluções criativas para melhorar suas vidas, das suas famílias e de suas comunidades.

Leituras sobre diferentes concepções de gênero e violência contra a mulher (VCM) sublinham o modo como os padrões de gênero estão enraizados, mas também destacam o fato de que tais padrões são transformáveis. Ao mesmo tempo, apontam que as análises sobre o tema do poder nas relações de gênero e sobre as concepções acerca do que é ser homem e do que é ser mulher no mundo contemporâneo são fundamentais para questionarmos os ditames culturais e identificar brechas para propor novos rumos para as relações entre homens e mulheres

\footnotetext{
${ }^{2}$ Este artigo é resultante da pesquisa de doutorado intitulada Feminismo de Base Comunitária em Contexto de Periferia Urbana: Iniciativas que Discutem Questões de Gênero na Maré (RJ).

${ }^{3}$ Para Judith Butler (1999) "o gênero não denota um ser substantivo", ou seja, não seria capaz de definir as identidades, os comportamentos e a sexualidade, bem como os discursos e performances dos indivíduos. Neste sentido, gênero pode ser entendido como um fenômeno fluído diretamente influenciado pelo contexto sociocultural em que o indivíduo está inserido, de modo que o gênero seria entendido enquanto uma construção histórica-cultural e não como algo natural-biológico. Assim, Butler defende que a noção de gênero (assim como a de sexualidade) deve ir além da dualidade macho-fêmea/homem-mulher/masculino-feminino, englobando todo o espectro de identidades, subjetividades e possibilidades que muitas vezes permanecem à margem diante das categorias heteronormativas vigentes.
} 
(NASCIMENTO \& SEGUNDO, 2011). Deste modo, desnaturalizar os processos de socialização de gênero e o uso assimétrico do poder por parte de homens (e de mulheres) e não tolerar que a VCM passe impunemente pela sociedade parece ser um caminho para a construção de relações mais justas e igualitárias (NASCIMENTO, 2014, p. 224).

É preciso destacar ainda que os aportes do feminismo pós-colonial consideram a subalternidade da mulher como resultado de uma dupla opressão, promovida pela soma da ideologia patriarcal à colonial (SPIVAK, 2010). Assim, este estudo parte da premissa de que a completa emancipação da mulher na sociedade brasileira, e no mundo, ainda representa uma realidade distante de ser alcançada. Além disso, o estudo foi pensado a partir de uma preocupação e inquietude com os altos índices da violência de gênero (VDG). Por outro lado, é importante lembrar que a mobilização popular, somada aos inúmeros indicadores existentes, justificou a criação de leis, campanhas, programas, convênios internacionais e uma série de esforços que levaram a avanços sociais, políticos e jurídicos no combate a este tipo de violência.

Portanto, este trabalho considera a perspectiva de que a VDG é uma expressão de desigualdades estruturais e também multidimensionais que colocam em risco a inclusão social das vítimas e de novas gerações - os filhos das vítimas (COSTA et al., 2015). Ela inclui o estupro, a violência doméstica, a mutilação, o homicídio, o abuso sexual, a coerção física e psicológica, e constitui um problema grave de saúde pública, em nível mundial (PITANGUY, 2011). A violência doméstica e a VCM são consideradas como formas de VDG, sendo entendidas como violações aos direitos humanos e se identificam como consequências dos fatores sociais relacionados a uma sociedade patriarcal-colonial. Apesar de VDM e VDG significarem fenômenos diferentes, as estatísticas existentes e a história brasileira demonstram que, na violência doméstica, eles estão sobrepostos. A VCM é aquela que emprega atos violentos contra mulheres por razões de gênero. Trata-se de um fato social que faz vítimas em todo o mundo. É preciso destacar que a VCM muitas vezes não se restringe as vítimas primárias, mas também afeta uma série de pessoas ligadas à vítima principal, sendo, portanto, um problema que afeta mulheres, homens, crianças, jovens, adultos e idosos. 
Dados da ONU apontam que os custos da violência contra as mulheres para a economia mundial representam cerca de 2\% do PIB global, aproximadamente 1,5 trilhões de dólares ${ }^{4}$. No caso do Brasil, estima-se que $40 \%$ das mulheres brasileiras já sofreram algum tipo de violência ao longo de suas vidas, que $66 \%$ dos brasileiros presenciaram uma mulher sendo agredida no ano de 2016 e que a cada hora duas mulheres são assassinadas, na maioria dos casos por parceiros ou parentes próximos ${ }^{5}$. Diante destas questões torna-se evidente a importância de uma educação que promova a igualdade de gênero, uma educação capaz de auxiliar no combate à VCM, representando, deste modo, uma pedagogia feminista que considere as realidades específicas das mulheres brasileiras, incluindo, as mulheres das periferias e suas comunidades.

Quanto ao grupo investigado, é importante dizer que o estudo investigou aspectos político-organizacionais e a ação engajada dessas sujeitas, observando as pedagogias que emergem desses contextos e, especificamente, as pedagogias voltadas para questões de gênero. Tal investigação foi desenvolvida por meio do cruzamento de observações participantes, conversas informais e entrevistas semiestruturadas.

Considerando que o feminismo de modo geral pode ser entendido como um movimento plural, composto por muitas correntes, visões, ideologias e lutas, neste trabalho o mesmo será abordado a partir de uma perspectiva fundamentada nas singularidades e demandas provenientes da própria comunidade, sendo, portanto, um feminismo que se desenvolve em torno de reflexões sobre problemas locais e, desse modo, entendido como um feminismo de base comunitária. Assim, a visão de um Feminismo plural destaca a diversidade nas linhas de pensamento dos estudos feministas, que abrangem múltiplas identidades e alianças presentes nos movimentos sociais. Neste sentido, como exemplos de vertentes dentro do feminismo, é possível citar: o feminismo liberal; feminismo radical; feminismo socialista; feminismo póscolonial $^{6}$; feminismo descolonial ${ }^{7}$; feminismo anti-colonial ${ }^{8}$; feminismo lésbico; feminismo

\footnotetext{
${ }^{4}$ Ver em: <www.onumulheres.org.br/noticias/onu-alerta-para-os-custos-da-violencia-contra-as-mulheres-no-mundo/>

${ }^{5}$ Ver em: <www.onumulheres.org.br/noticias/onu-alerta-para-os-custos-da-violencia-contra-as-mulheres-no-mundo/>

${ }^{6} \mathrm{O}$ feminismo pós-colonial parte da teoria pós-colonial que, por sua vez, influenciou o desenvolvimento da teoria e do feminismo decolonial. A teoria pós-colonial surge a partir das guerras de independência na Ásia e África, tomando tais eventos como um ponto de partida histórico para entender relações de opressão e invisibilização impostas pela sociedade ocidental, incluindo os estudos sobre subalternidade, apresentando grande influência dos estudos linguísticos.
} 


\section{novist

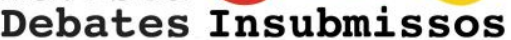

negro; feminismo indígena; ecofeminismo; além de outros. Assim, partimos da perspectiva de que, no Brasil, muitas vezes as mulheres identificadas como feministas nem sempre se autodeclaram $^{9}$ como tal; porém, diante de suas atitudes, posicionamentos e ações, torna-se possível identificar traços do que seria entendido como um feminismo que apresenta fortes influências do feminismo negro, mas ao mesmo tempo se utiliza de fundamentos provenientes de outras vertentes do feminismo.

Assim, entendo que os conhecimentos destas mulheres devem ser valorizados não só porque são produtoras de processos sociais, mas porque podem fornecer outras perspectivas válidas e ricas para a Educação, Ciências Sociais e para os Estudos Feministas. Elas representam as formas pelas quais mulheres da periferia estão desconstruindo e descolonizando modos de pensar e, subsequentemente, mudando formas de agir. Enfim, as práticas dessas mulheres podem contribuir para a discussão sobre o que seria um feminismo do Sul, um feminismo proveniente das periferias da América Latina e, portanto, um feminismo tecido a partir das perspectivas e contextos brasileiros, sendo, assim, um feminismo de base comunitária.

O foco deste trabalho são as mulheres-sujeitas. O trabalho dessas mulheres envolve iniciativas educativas sobre questões de gênero em estruturas distintas, que vem sendo desenvolvidas na Maré - um território onde existem fatores que refletem a relação entre a sociedade civil e o Estado (exemplos: falta de serviços básicos, a violência armada entre facções rivais e com a polícia, existência de preconceitos impostos aos moradores etc) -, no que se refere ao afastamento do Estado de sua responsabilidade com os direitos sociais dos moradores, e a transferência deste dever às organizações e instituições da sociedade civil. Neste sentido,

\footnotetext{
${ }^{7} \mathrm{O}$ feminismo decolonial, assim como a teoria decolonial, parte do momento histórico da invasão-dominação da América pelos povos europeus, datado a partir do ano de 1492. O Feminismo decolonial entende que o fim do colonialismo não representou o fim da colonialidade, de modo que a colonialidade, neste sentido, é entendida como uma sequela do processo colonial. Assim, o Feminismo Decolonial representa um projeto político que entende que a teoria deve caminhar junto das práticas políticas coletivas e entende que as experiências dos indivíduos nas lutas sociais produzem teorias e conhecimentos, contrariando uma concepção de feminismo hegemônico, que se baseia em uma série de privilégios construídos a partir de critérios de raça, classe social, status etc. É preciso destacar que o feminismo decolonial, assim como a teoria decolonial incorporam fundamentos da teoria anti-colonial, do feminismo anti-colonial e do feminismo anti-racista.

${ }^{8}$ A concepção de um feminismo anti-colonial se baseia na ideia de lutar contra as formas de poder colonial, estando ligado ao feminismo anti-racista.

${ }^{9} \mathrm{O}$ conceito de feminismo no Brasil muitas vezes assume uma conotação pejorativa, devido aos discursos vinculados a grupos políticos e setores conservadores da sociedade.
} 
este trabalho se apoia na ideia de que os movimentos sociais combinam uma diversidade de padrões de interação com o Estado.

No conjunto da Maré existe uma série de iniciativas identificadas como projetos sociais. Tais projetos são elaborados e implementados por organizações privadas que trabalham na esfera de interesse público. É preciso destacar que os temas de gênero e direitos de mulheres foram encaixados nos últimos 8 anos nos esforços dessas instituições de uma forma mais intensa. Destaco que a pesquisa partiu da hipótese de que a percepção das atrizes varia conforme o tipo de organização em que estão inseridas. Não se trata de revelar aqui uma nova história, uma novidade; trata-se de visibilizar o que foi feito, o que está sendo realizado neste momento e o que continuará como um legado destas mulheres para suas comunidades. As experiências estudadas nesta pesquisa focam nas perspectivas de mulheres dos territórios, de mulheres das periferias da América Latina, de mulheres que resistem em contextos de violências e que, em meio a esses contextos, produzem pedagogias criativas. Assim, este trabalho pretende descobrir que tipo de conhecimentos pedagógicos sobre questões de gênero são produzidos por mulheres no contexto do Conjunto de Favelas Maré, chamando a atenção para a necessidade de a academia ouvir tais vozes dos territórios e, em especial, as vozes das mulheres das periferias.

\section{APORTES TEÓRICOS}

O estudo considera a realidade da Maré, assim como das periferias da América Latina, como um resultado do que o escritor Eduardo Galeano chamou de "abertura das veias da América", somado ao que autores dos estudos pós-coloniais e decoloniais se referem por colonialidade, que seria uma das formas como a Modernidade se expressa. Dentro deste grupo de autores citados anteriormente, Enrique Dussel (1993) considera que a formação da modernidade teve início com a colonização do território de Abya Yala ${ }^{10}$, de modo que o controle desse território resultou de um projeto de imposição de uma cultura alienígena sobre as

\footnotetext{
${ }^{10}$ Nome dado pelo povo Kuna, originário da Serra Nevada, no norte da Colômbia, ao território que atualmente conhecemos como o continente americano.
} 
culturas endêmicas, acrescido a um processo de exploração e expropriação que deixou marcas nas paisagens, memórias, histórias, corpos e culturas. Assim, para o autor (op cit) a modernidade ocidental depende do colonialismo que por sua vez, possibilitaram o desenvolvimento do capitalismo global. Deste modo, entende-se que o capitalismo sem o colonialismo não seria possível, sendo a base fundamental deste processo construído sobre a modernidade ocidental, fundamentada no paradigma de que o ser humano é equivalente ao Homem-branco-europeu-heterossexual do norte global. Em outras palavras, Dussel entende que a América é um produto da tríplice colonialismo-capitalismo mundial-modernidade ocidental.

Para Mignolo (2007), a modernidade se expressa de três formas distintas: através do mito salvacionista do progresso, que aponta o progresso científico e tecnológico da sociedade ocidental como uma maneira de superar todo tipo de problemas da humanidade e que engloba a concepção de que povos não-ocidentais representariam um estágio de pré-civilização que colocaria os europeus em uma posição de "salvadores dos selvagens", como se os nativos precisassem destes para "evoluir enquanto sociedades"; para além do mito salvacionista, a modernidade também se expressa por meio dos traumas e consequências produzidos pelo processo de colonização que resultam no que os autores do grupo ModernidadeColonialidade ${ }^{11},{ }^{12}$ chamam de colonialidade.

O conceito de colonialidade, por sua vez, se expressa de diferentes formas: a colonialidade do poder (QUIJANO, 2010), que corresponde à hierarquia racializada ${ }^{13}$ imposta pelo processo colonial; a colonialidade do saber (PORTO-GONÇALVES, 2005), que considera a distribuição do conhecimento e o reconhecimento dos saberes norte-eurocêntricos como sendo superiores aos demais, bem como o saber científico em detrimento dos saberes populares; e a colonialidade do ser (MALDONADO-TORRES, 2010), que corresponde a um resultado da colonialidade do poder que molda a existência dos indivíduos de acordo com suas posições na hierarquia racializada da sociedade moderna ocidental. Por fim, a modernidade apresenta uma

\footnotetext{
${ }^{11}$ O Grupo de estudos Modernidade-Colonialidade, constituído no final dos anos 1990 e formado por intelectuais latino-americanos de diferentes universidades e centros das Américas, propõe uma renovação epistemológica das ciências sociais na América Latina (BALLESTRIN, 2013).

${ }^{12}$ Destaco a forte influência deste grupo para construção da teoria do Feminismo Decolonial.
} 


\section{Revista \\ Debates Insubmissos}

última faceta, que se posiciona como uma força de resistência contra a colonialidade, a decolonialidade. Considerando esta perspectiva da Decolonialidade enquanto uma força de resistência à colonialidade, assumimos a seguinte concepção de resistência, enunciada por Lugones (2014, p.940) que entende que "[a] resistência é a tensão entre a sujeitificação (a formação/informação do sujeito) e a subjetividade ativa, aquela noção mínima de agenciamento necessário para que a relação opressão-resistência seja uma relação ativa.”.

Ao pensar uma alternativa diante das injustiças e dos apagamentos exercidos pelo processo colonizador, no sentido da busca pela libertação do eurocentrismo imposto, Curiel (2015), falando sobre Aimee Cesarie e Frantz Fannon (1977 apud CURIEL, 2015), entende que a descolonização representa não apenas uma independência entre metrópoles e colônias, ou entre países no norte e do sul global, mas sim um rompimento das relações de poder e de concepções de conhecimento que produzem a reproduzem hierarquias raciais, geopolíticas e de "imaginários" que foram criados no contexto das sociedades ocidentais e coloniais. Deste modo, este trabalho parte de uma concepção de que o machismo e a subalternização da mulher na sociedade moderna ocidental consistem em expressões da colonialidade e, portanto, devem ser combatidos a partir de práticas decolonais. É importante destacar que originalmente as teorias de colonialidade e modernidade não consideravam as implicações do gênero nas relações de poder dentro da sociedade ocidental. Tal entendimento parte dos trabalhos de Lugones (2014) que destaca a importância de conceituar o gênero como uma das formas de opressão colonial e ressalta a necessidade de construir um feminismo que questione os padrões eurocêntricos. Esta visão de Lugones (op cit) foi desenvolvida a partir de uma crítica a forma como Quijano abordou o conceito de gênero em seus trabalhos sobre Colonialidade do Poder ${ }^{14}$, destacando que tal autor baseia sua crítica à modernidade-colonialidade a partir de uma concepção eurocêntrica de gênero, que ao tratar sexo como algo estritamente biológico ignorou a intersecção desta categoria com outras. Maldonado-Torres apresenta uma definição para os conceitos de colonialidade e colonialismo ressaltando as diferenças e conexões entre os termos:

O colonialismo denota uma relação política e econômica, na qual a soberania de um povo está no poder de outro povo ou nação, o que constitui a referida

\footnotetext{
${ }^{14}$ Para a autora, a maneira como Quijano apresentou o conceito de gênero invisibiliza a forma como as mulheres colonizadas, não-brancas, foram subordinadas e oprimidas.
} 


\section{Revista \\ Debates Insubmissos}

nação em império. Diferente desta ideia, a colonialidade se refere a um padrão de poder que emergiu como resultado do colonialismo moderno, mas em vez de estar limitado a uma relação formal de poder entre dois povos ou nações, se relaciona à forma como o trabalho, o conhecimento, a autoridade e as relações intersubjetivas se articulam entre si através do mercado capitalista mundial e da ideia de raça. Assim, apesar do colonialismo preceder a colonialidade, a colonialidade sobrevive ao colonialismo (2007, p. 131).

Conforme o conceito Sistema Moderno-Colonial de Gênero desenvolvido por Lugones (2014) a colonialidade do poder é sustentada por diferentes formas de dominação, em especial a dominação baseada em critérios de raça e de gênero. Assim, a hierarquia identificada no Sistema de gênero, além de considerar o gênero em si, também abarca aspectos da racialidade e da sexualidade (LUGONES, 2014). Sobre a perspectiva do que seria uma Pedagogia Decolonial, Walsh afirma que seriam:

Metodologias produzidas em contextos de luta, marginalização, resistência e que Adolfo Albán tem chamado re-existência; pedagogias como práticas insurgentes que fraturam a modernidade/colonialidade e tornam possível outras maneiras de ser, estar, pensar, saber, sentir, existir e viver-com (2010, p. 19).

Considerando a existência de distintos níveis na formação das identidades e subjetividades das populações subalternas, é possível entender que, para compreender os contextos e singularidades destes grupos, torna-se preciso um esforço integrador, capaz de reconhecer esses distintos níveis que conformam tais identidades e subjetividades. Neste sentido, Kimberly Crenshaw (1991) desenvolve o conceito de interseccionalidade a partir de observações acerca de como as discriminações raciais e de gênero têm sido dissociadas, e de como no processo de positivização dos Direitos Humanos, a incorporação da categoria gênero alcançou uma inserção distinta do que ocorreu com a raça, acarretando, desta forma, dificuldades de compreensão da "discriminação interseccional". Deste modo, a interseccionalidade vai tratar, sobretudo, da associação de diferentes eixos de subordinação e opressão, em outros termos, visa abordar "a forma pela qual o racismo, o patriarcalismo, a opressão de classe e outros sistemas discriminatórios criam desigualdades básicas que estruturam as posições relativas de mulheres, raças, etnias, classes e outras" (CRENSHAW, 1991, p. 177). Numa mesma linha de pensamento, pode-se refletir acerca do trabalho de Spivak 


\section{Revista
Debates Insubmissos}

(2010), considerando que as classes subalternas muitas vezes acumulam distintos níveis de subalternidade.

O mestre quilombola Antônio Bispo dos Santos (2015) entende que o conhecimento pode ser separado em duas classes: o saber sintético, representado pelos conhecimentos acadêmicos-científicos, que são predominantemente teóricos; e, por outro lado, o chamado saber orgânico, que seria aquele proveniente das próprias comunidades, ou seja, um saber construído a partir das relações cotidianas, um saber que muitas vezes resulta de um acúmulo de conhecimentos empíricos transmitidos de geração em geração e, portanto, trata-se de um saber da prática. Assim, Bispo (op cit) destaca a necessidade de uma confluência entre tais saberes, ou seja, um encontro entre o saber científico e o saber popular a fim de produzir um terceiro, e novo, saber, construído a partir da hibridização dos conhecimentos desenvolvidos pelo povo e aqueles produzidos nas universidades.

Essa perspectiva defendida por Nego Bispo se aproxima da visão de Boaventura de Sousa Santos de uma Ecologia de Saberes, ou seja, uma estratégia de articulação entre diferentes saberes a fim de superar a monocultura de conhecimentos promovida pelo que o autor se referiu por conhecimentos abissais, ou seja, uma visão que não permite o diálogo entre diferentes perspectivas de conhecimento, entre diferentes epistemologias e epistemes. Neste sentido, esta pesquisa se propõe a servir de espaço para a produção de confluências entre o saber orgânico, das comunidades, e o saber sintético, das universidades.

Uma ferramenta que se tem utilizado para desnaturalizar os padrões de gênero é a educação popular de Paulo Freire. Baseada no saber da comunidade (entendido como saber orgânico na visão de Antônio Bispo (2015)), a educação popular incentiva o diálogo, e ajuda os indivíduos a apropriarem-se do conhecimento-conscientização necessário para superar a opressão e atingir a transformação social. A educação popular, como campo de conhecimento e como prática educativa, vincula o ato de ensinar com a política, no intuito de contribuir para a construção de processos de resistência e para a emancipação humana. É o que discute Brandão, 
em sua análise dos quatro tipos de educação popular ${ }^{15}$, na qual distingue a educação popular como campo de conhecimento, definindo-o como:

Um saber da comunidade torna-se o saber das frações (classes, grupos, povos, tribos) subalternas da sociedade desigual. Em um primeiro longínquo sentido, as formas - imersas ou não em outras práticas sociais - através das quais o saber das classes populares ou das comunidades sem classes é transferido entre grupos ou pessoas, são a sua educação popular. (BRANDÃO, 2007, p. $16)$.

O que se busca refletir é esse processo, que se soma aos esforços realizados por mulheres educadoras que assumem a concepção educativa trabalhando questões de gênero e feminismo na educação não formal na Maré. Trata-se de uma educação popular que emerge do território, das próprias comunidades, tecida pelos seus próprios habitantes no sentido de transformar a realidade local sendo, portanto, também entendida como uma educação de base comunitária. Desse modo, esta pesquisa identifica traços de uma educação popular nas ações que visam combater a desigualdade de gênero, realizadas pelas mulheres investigadas.

Considerando que uma perspectiva de Feminismo de Base Comunitária se estabelece com fortes influencias da Educação Popular, trago o aporte de Paulo Freire ${ }^{16}$ para entender alguns pontos da ação política produzida por estas mulheres. Em um primeiro momento, a situação da VDG e a VCM aparecem como uma condição naturalizada, como contradições que envolvem os invidíduos representando obstáculos de difícil superação, ou, em outras palavras, barreiras que atrapalham a melhoria das condições de vida da comunidade. Neste sentido, entendo que a VDG, VCM e a Desigualdade de Gênero representariam, em uma perspectiva Freireana, uma Situação-Limite (FREIRE, 1987) a ser superada por estas comunidades. Ao decidir modificar suas realidades em torno da resolução de um problema real, neste caso representado pela situação limite, as mulheres passam a se organizar e a produzir saberes e

\footnotetext{
${ }^{15}$ Brandão identifica quatro diferentes sentidos da educação popular: 1) como a educação da comunidade primitiva anterior à divisão social do saber; 2) como a educação do ensino público; 3) como educação das classes populares; 4) como a educação da sociedade igualitária (2007, p. 3).

${ }^{16}$ No verbete Feminismo, do Dicionário Paulo Freire, Márcia Alves da Silva (2016) afirma que embora Freire não tenha trabalhado especificamente com a discussão feminista em sua obra, sua teoria da Educação Dialógica pode auxiliar a criar condições para a emancipação de mulheres e superação de relações sociais sexistas. Por outro lado, a autora destaca que Freire chegou a receber críticas de feministas por utilizar de uma linguagem masculina, mas entende que a o autor empreendeu um esforço para adequar-se às críticas, passando, com o tempo a empregar uma linguagem mais inclusiva.
} 


\section{Revista
Debates Insubmissos}

fazeres necessários para superar uma situação de opressão naturalizada, deste modo, esta organização, em torno de iniciativas, grupos, coletivos e redes poderia ser entendida como o que Freire (1987) chama de Ato Limite, ou seja, a ação necessária para transpor uma situação limite visando atingir uma condição idealizada e transformadora que, neste caso seria representada pela ausência de uma das formas de violência nas comunidades, ou seja, um Inédito Viável (FREIRE, 1987).

Ainda com relação aos aportes de Paulo Freire para uma perspectiva de Educação de Base Comunitária que parte de uma articulação entre Pedagogia Crítica e Educação Decolonial, embora o autor não esteja diretamente vinculado ao grupo Modernidade-Colonialidade destaco algumas influencias de Freire para a construção práticas decoloniais como apontado por MottaNeto (2016) em sua tese de doutorado, onde afirma que as principais contribuições de Freire neste sentido correspondem às seguintes críticas: 1) crítica à inexperiência democrática da sociedade brasileira; 2) crítica a desumanização/massificação/coisificação do ser humano; 3) Crítica à teoria antidialógica da opressão e, em especial, à invasão cultural; 4) crítica ao problema da dependência das relações imperialistas e neocoloniais entre $1^{\circ}$ e $3^{\circ}$ mundos; 5) crítica à educação e aos sistemas de ensino coloniais; 6) crítica à razão determinista da modernidade e à pós-modernidade neoliberal. Assim, com base neste aporte de Freire, é fundamental encarar a realidade da Maré, assim como de outras periferias do Brasil e da América Latina, a partir de uma abordagem que considere os impactos resultantes não apenas da luta de classes, mas também da dimensão da colonialidade que, nestes contextos, influenciam diretamente na própria conformação e manutenção desta estrutura social marcada por desigualdades. Neste sentido, Freire (1982) afirma que a educação comunitária deve ir além do ambiente escolar, visto que:

Não podemos esperar que uma escola seja "comunitária" numa sociedade de classes. Não podemos esquecer que a escola também faz parte da sociedade. Ela não é uma ilha de pureza no interior da qual as contradições e os antagonismos de classe não penetram. Numa sociedade de classes toda educação é classista. E, na ordem classista, educar, no único sentido aceitável, significa conscientizar e lutar contra essa ordem, subvertê-la. Portanto, uma tarefa que revela muito mais o conflito interior à ordem classista do que a busca de um diálogo que instaure a comunhão de pessoas ou de classes (p. 13). 


\section{Debates Insubmissos}

Revista

\section{PERCURSO METODOLÓGICO}

Esta pesquisa emprega uma abordagem qualitativa que tem como base o pensamento crítico feminista, as teorias decolonial e pós-colonial, a educação popular e a prática política. $\mathrm{Na}$ busca de estudar as experiências e percepções de mulheres que implementam iniciativas voltadas a igualdade de gênero e o processo vivenciado por elas, optei por empregar uma mistura de métodos qualitativos que incluem as seguintes técnicas: observação participante; entrevistas individuais (e duas entrevistas em grupo); e estudos bibliográficos. Também foram utilizados como fontes de informação os materiais produzidos pelas mulheres que implementam estas inciativas voltadas a questão da igualdade de gênero, incluindo os cartazes de eventos, materiais de divulgação das atividades, listas de leituras utilizadas para abordar temáticas de Educação de Gênero com mulheres, os cronogramas das atividades das iniciativas, além de banners e pôsteres produzidos. A metodologia desta pesquisa se divide em dois momentos: a coleta de dados (atividade de campo) e a análise dos dados (pós-campo). Para a metodologia de coleta de dados foram empregadas as técnicas de entrevista semiestruturada, conversas informais e observação participante, tendo os informantes sido selecionados por meio de critério de reconhecimento social. Para a metodologia de análise foi eleita a abordagem de Análise de Conteúdo de Bardin (2011) para auxiliar na organização e interpretação dos dados revelados. Para os fins deste artigo optei focar em alguns dos resultados levantados através das entrevistas semiestruturadas.

O recorte deste estudo se deu em torno das experiências e perspectivas de mulheres de grupos distintos e de diferentes comunidades localizadas no conjunto de favelas da Maré ${ }^{17}$, área periféricada cidade do Rio de Janeiro, uma das maiores favelas do estado. Fica às margens da Baía de Guanabara, entre três importantes vias de acesso: a Avenida Brasil, a Linha Vermelha e a Linha Amarela. A Maré é rodeada por áreas de grande importância econômica, que a colocam

\footnotetext{
${ }^{17}$ Neste trabalho utilizarei o termo Conjunto de Favelas ao invés de Complexo, pois o termo Complexo costuma ser visto de forma pejorativa, estando ligado a uma discriminação discursiva dos territórios que associa os moradores destes territórios ao sistema penitenciário. É preciso destacar que os moradores da Maré que contribuíram para este estudo costumam se identificar como: a) moradores das comunidades em que vivem, referindo-se aos nomes específicos destas comunidades; b) como moradores da Maré; c) como moradores de Bom Sucesso (quando se referindo a pessoas desconhecidas ou de fora da comunidade).
} 
em posição geográfica privilegiada. O conjunto é composto por 16 favelas, com diferentes características entre si, que apresentam suas próprias associações de moradores e distintos contextos históricos. As favelas que fazem parte do Conjunto de favelas da Maré são: Baixa do Sapateiro; Morro do Timbau; Parque Maré; Nova Maré; Nova Holanda; Rubens Vaz; Parque União; Conjunto Esperança; Conjunto Pinheiros; Vila do Pinheiro; Vila do João; Salsa e Merengue; Marcílio Dias; Roquete Pinto; Praia de Ramos; e Bento Ribeiro Dantas. Nesta pesquisa as iniciativas voltadas para a discussão de questões de gênero na Maré que foram observadas nesta pesquisa incluem às seguintes: sede da Centro de Referência da Mulher na Maré (CRMM) na Vila do João; a Luta Pela Paz na Nova Holanda; Casa da Mulher - Parque União; Mulheres ao Vento - Centro das artes da Maré (CAM); Espaço Casulo - Morro do Timbau.

Segundo Diniz, Belfort e Ribeiro (2012, p. 19), mesmo com alguns programas de urbanização implementados no século passado, a maioria da população da Maré acabou não sendo reconhecida pelo estado como merecedora dos serviços públicos básicos, o que reflete no descaso do poder público em relação a este território e sua população. É importante destacar que, assim como ocorre em muitas comunidades de periferias da América Latina, a presença da violência é algo marcante que inclusive assume um papel na constituição das identidades dos indivíduos destas localidades. No caso da Maré é possível identificar muitas formas de violência, incluindo não somente a VDG, VCM e violência doméstica, mas também a violência armada perpetrada não somente pelo poder paralelo, mas também pelo próprio Estado, sob a forma de violência policial. A pesquisadora e militante Marielle Franco (2014), em sua dissertação de mestrado, destacou algumas características específicas deste território, chamando a atenção para a contraditória relação de ausência-presença do Estado nestas comunidades, ressaltando, de um lado à ação de militares, de outro, a insuficiência/interrupção de serviços básicos. Neste sentido, embora se localize em uma área da cidade considerada de fácil acesso, ainda assim o território da Maré apresenta restrições à circulação dos moradores e mesmo de prestadores de serviço:

O Complexo da Maré, [foi] alvo de inúmeras operações sob a justificativa de repressão ao tráfico de drogas e posterior implantação de uma unidade de polícia pacificadora (UPP) [...]. Seu entorno são os bairros de Bonsucesso, 


\section{norstat 0 \\ Debates Insubmissos}

Ramos, Caju e a Ilha do Governador, que vivem no limiar dos confrontos. As 16 comunidades circunscritas ao bairro Maré vivenciam uma tragédia iminente. No dia a dia de escolas, postos de saúde, somente a permanência física de seus equipamentos - que são prédios públicos construídos ou em funcionamento -, não soluciona, ou não garante um atendimento de qualidade para os moradores. A Maré é um bairro de fácil acesso, dado que está situada às margens da Av. Brasil e Linha Amarela e Vermelha (vias de grande importância para o estado do Rio de Janeiro). Porém, sempre há relatos de ausência de professores e médicos, por exemplo (2014, p.97).

Neste sentido é preciso lembrar que a violência nestes casos atinge uma grande parcela desta população, restringindo inclusive a circulação de pessoas em meio a estes territórios e produzindo "leis invisíveis" que valem dentro das fronteiras destas comunidades, assim, os moradores destas áreas são afetados de diferentes maneiras (ex: assassinatos/morte de parentes, estigmas associados à população local, repressões etc).

Historicamente, os moradores da Maré, em especial as mulheres, sempre atuaram no sentido de lutar pela melhoria das condições de vida de suas comunidades. Neste sentido, destaco a importância do movimento associativo intitulado "Chapa Rosa" que foi desenvolvido a partir do final da década de 1970, instalado na comunidade de Nova Holanda, e que atuou à frente da associação de moradores por cerca de 9 anos, promovendo uma série de mudanças no espaço da favela, de modo a gerar uma nova forma de relação dos moradores com aquele espaço, auxiliando no fortalecimento das identidades locais (CARVALHO, 2006). Neste estudo a Maré será entendida como "periferia-território-resistência", para empregar a compreensão sobre esta área considerada por Raúl Zibechi (2015) e Timo Bartholl (2016), quando colocam ênfase na necessidade de se compreender as periferias como parte da luta pela transformação radical da sociedade.

Ainda que as iniciativas a serem estudadas e analisadas não tenham a violência de gênero (VDG) como foco principal, o fato de terem a perspectiva de gênero como pedra angular faz de seu estudo algo importante para a compreensão da ligação entre as micropolíticas de contexto, subjetividades, resistências, as políticas macro da economia global, os sistemas políticos e processos (MOHANTY, 2013) que afetam o combate à desigualdade de gênero.

Com base nas informações reveladas a partir da revisão bibliográfica, somadas aos resultados das observações participantes, foi possível estabelecer um roteiro para entrevistar as 
mulheres identificadas como informantes estratégicas para compreender a educação de gênero na Maré. O roteiro que consiste de vinte perguntas foi desenvolvido, incluindo perguntas fechadas que fornecem informações básicas (idade, raça, nível escolar etc.) sobre as mulheres, além de perguntas abertas focados no problema de investigação. As entrevistas foram realizadas no espaço da instituição, no mesmo horário em que eles e elas costumam frequentar e durou entre meia hora e uma hora e meia. Para as entrevistas semiestruturadas foram selecionados 17 sujeitas- mulheres, escolhidas em função de suas participações em contextos sociais e envolvimento nas atividades e práticas da iniciativa focada na igualdade de gênero. Com exceção de três entrevistadas a maioria mora $^{18}$ na Maré, na Zona Norte e na Ilha do Governador. Do número total de mulheres (17) entrevistadas que fazem parte das equipes de coordenação das iniciativas voltadas à questão da igualdade de gênero, 11 são moradoras da Maré, sendo residentes das comunidades Parque Maré, Nova Holanda, Rubens Vaz, Marcilio Dias e Moro do Timbau. Ainda com respeito ao local em que residem as mulheres participantes desta pesquisa, onze se identificaram como moradoras da Maré, sendo cinco destas residentes de Nova Holanda. Com a exceção de uma mulher entrevistada, a maioria delas são moradoras da Maré e implementam suas iniciativas voltadas a igualdade de gênero nas suas respectivas comunidades ou em comunidades próximas. Além das entrevistadas que residem na Maré, quatro moram na zona norte e duas em bairros da zona sul.

Foi realizada uma Análise de Conteúdo, seguindo a concepção de Bardin (2011), onde foram considerados os silêncios, as expressões e hesitações que as mulheres expressaram durante as entrevistas. Bardin (2011) entende a Análise de Conteúdo como um método que emprega um conjunto de técnicas de análise de comunicação descrevendo os conteúdos das mensagens de forma objetiva e sistemática. Neste sentido, a sistematização dos dados foi realizada em quatro etapas: 1) a primeira consistiu de uma leitura horizontal dos dados para obter uma compreensão de cada entrevista e detalhes sobre seu contexto; 2) a segunda etapa, mais rigorosa, corresponde à sistematização dos dados em focos temáticos que resultou na identificação de categorias analíticas, nesta etapa também foram identificadas as palavras e expressões recorrentes que surgiram a partir da análise do que foi dito nas entrevistas; 3) na

\footnotetext{
${ }^{18}$ Cabe ressaltar que uma das entrevistadas que atualmente reside na Zona Sul foi criada em Irajá
} 
terceira etapa foi realizada uma sistematização vertical onde se comparou o conteúdo dos distintos focos temáticos nos diferentes casos; 4) na última etapa da sistematização dos dados, buscaram-se identificar as recorrências, pontos de convergência e divergência e o estabelecimento de relações com variáveis importantes como, por exemplo, classe social e raça.

\section{RESULTADOS E DISCUSSÃO}

Das dezessete mulheres entrevistadas seis são casadas ou moram com seus parceiros. Além disso, é interessante ressaltar que as entrevistadas têm entre 2 a 14 anos trabalhando nas organizações e grupos onde desenvolvem as iniciativas voltadas a igualdade de gênero. Doze trabalham dentro de organizações sem fins lucrativos (ONGs) (em duas instituições diferentes), três implementam suas iniciativas através de um projeto autônomo e duas desempenham atividades ligadas a questão da igualdade de gênero em um espaço reconhecido como autônomo e feminista. A faixa etária das entrevistadas varia entre 26 e 60 anos de idade. Conforme as respostas das entrevistas e questões iniciais do roteiro de pesquisa foi possível perceber que nove estão na casa dos trinta anos, três possuem idades entre 26 e 29 anos e quatro encontramse na faixa etária acima dos quarenta anos.

A respeito da categoria cor/raça, a maioria (12) das mulheres que participaram da pesquisa se identificaram como sendo pertencentes à raça negra. Quatro das mulheres consideram-se brancas e uma reconheceu-se como parda. Das sujeitas que trabalham e moram na Maré oito se identificaram como negras. Em termos socioeconômicos ${ }^{19}$ treze das dezessete mulheres se entendem como de baixa renda enquanto quatro se identificam como pertencentes à classe média. As mulheres de baixa renda são moradoras da Maré ou outras partes da Zona Norte. Neste sentido, ressalto que a renda média mensal ${ }^{20}$ das mulheres pertencentes às organizações de base está em torno de $\mathrm{R} \$ 1.120,00$.

\footnotetext{
${ }^{19}$ Destaco o fato de que nem todas as mulheres se sentiram à vontade para divulgar seus salários específicos. Neste sentido, as entrevistadas apenas identificam como se entendem com relação à suas condições socioeconômicas.

${ }^{20}$ É preciso frisar o fato de que boa parte dos ganhos financeiros destas mulheres está associada a outras atividades profissionais para além de suas atuações com as iniciativas investigadas. Como exemplos de atividades extras apontadas pelas entrevistadas estão atividades docentes (ex: aulas de gênero), produção de artesanatos, bolsas de estudos etc.
} 
Em termos de nível de escolaridade, quinze das dezessete mulheres, possuem ensino superior completo ou estão cursando. Quatro mulheres estavam cursando o ensino superior no momento das entrevistas, cinco já haviam completado a graduação e cinco já tinham completado cursos de pós-graduação, sendo que uma das entrevistadas estava para completar seu doutorado. Duas das mulheres possuem ensino médio completo.

É importante destacar que as mulheres participantes da pesquisa não identificaram suas práticas com as teorias decolonial e pós-colonial, mas, a partir de uma reflexão sobre as atividades realizadas com base nas discussões teóricas destes campos, foi possível identificar nestas ações elementos que poderiam ser entendidos como decoloniais ou pós-coloniais.

\section{ESPAÇO, RECONSTRUÇÃO E REPRESENTAÇÃO}

As lutas têm sido para ocupar as instituições que mantêm a exclusividade do conhecimento, mas também criar seus espaços de produção e diálogos de conhecimentos produzidos (ARROYO, 2012). Nas entrevistas, surgiram as categorias de espaço, reconstrução e representação nos discursos das entrevistadas. Uma característica que todas as entrevistas tiveram em comum é o destaque do desejo de um espaço, como lugar de reconstrução de subjetividades e representação ${ }^{21}$, um lugar necessário e desejado por parte das entrevistadas, que aparece relacionado à concepção de resistência. Aqui, utiliza-se as categorias de Espaço, Reconstrução e Representação para sublinhar a necessidade de lutar contra percepções e arranjos de poder relacionados com o patriarcado moderno e a cultura machista, no mesmo tempo, construindo e levantando subjetividades relacionadas à questão de "quem é esta mulher da Maré?", “quem são as pessoas que moram nesta localidade?” e “o que representa este território?”, destacando os aspectos que podem servir para resistir às situações de opressãoinvisibilização-subalternização rumo à construção de ações políticas. Deste modo, estes espaços

\footnotetext{
${ }^{21}$ Neste caso Representação está relacionado ao lugar e ao indivíduo que vive neste lugar, em outras palavras, está associado ao processo de formação de identidades como indivíduos/morador (a) e suas percepções de si e de seu mundo, entendendo que a realidade vivenciada pelas comunidades vai além dos estigmas associados à estas populações, partindo de uma visão de que a definição imposta por outros acerca da realidade local deve ser questionada e substituída por uma visão autóctone, produzida a partir das subjetividades dos moradores do território.
} 


\section{Revista \\ Debates Insubmissos}

de reconstrução e representação estão diretamente relacionados aos processos de resistência destas mulheres às múltiplas opressões ocasionadas pelo sistema capitalista neoliberal global, partindo de uma reflexão crítica acerca da realidade local e de sua condição enquanto oprimido e as estratégias disponíveis para enfrentar esta opressão. Com base nesta perspectiva, uma das entrevistadas relatou o seguinte:

Primeiro, todo mundo pensa “o Estado não está aqui!", "ele não está presente", na verdade, ele está presente e está determinando como o morador da Maré vai se colocar na sociedade, que vai ser o morador sem qualificação e que vai dar conta destes trabalhos que são mal remunerados, que vai dar conta desses estigmas da sociedade onde coloca a mulher também nesse lugar, porque ele não vai ter outro parâmetro. $O$ Estado está presente manipulando o morador a seguir esse padrão de população pobre, sem acesso e naturalizando isso, fazendo com a que a população naturalize essa "não presença" deles aqui. Então isto está ligado aos grupos civis armados, está ligado a educação, está ligado ao não acesso à saúde, e sempre muito tentando naturalizar esses problemas. A grande questão do projeto é fazer com que as mulheres se organizem de outra forma e questionem o Estado, questionem a necessidade de direitos, e essas necessidades de direitos estão ligadas à várias frentes.

É preciso destacar que o posicionamento das participantes em relação ao sistema neoliberal evidenciou duas posições possíveis: as que permanecem autônomas, resistindo de maneira mais intensa a uma vinculação institucional formal que requer financiamento de órgãos privados e instituições vinculadas ao "sistema de desenvolvimento"; e, por outro lado, aquelas que partem da visão de que seria possível mudar o sistema de dentro para fora, ou, em outras palavras, que a transformação social pode ser alcançada a partir de movimentos institucionais. No entanto, durante as entrevistas todas as mulheres destacaram a falta de espaços específicos para discutir, compartilhar e refletir sobre questões de gênero.

Alguns autores apontam para a necessidade de conceitualização do conceito de "lar" em relação à identidade e à comunidade como categoria de poder (ISOKE, 2013; MOHANTY \& MARTIN, 2003). O conceito de lar para estes autores está conectado tanto com a ideia de pertencimento como de libertação e o olhar para si mesmo. Um pouco mais da metade das mulheres expressaram suas intenções de criar estes espaços ligados a desejos que tinham a respeito da Maré, seu "lar," comunidade onde elas morram. Seja através do desejo de contribuir para a mudança social no território ou participar de ações que as ajudam a exercer algo que pelas estruturas de dominação não conseguiam, mulheres entrevistadas destacaram a 


\section{Revista \\ Debates Insubmissos}

necessidade da criação destes espaços. Uma mulher comentou que sua participação na inciativa voltada a questão de gênero a permitiu trabalhar com o que ela vem há anos trabalhando, mas por questões tradicionais, fundamentadas no patriarcado e padrões de gênero, ela nunca conseguiu exercer. Ela comentou o seguinte:

Então, o Candomblé é uma religião altamente paternalista, então a mulher tem uma série de incumbências, mas a mulher nunca está em destaque no Candomblé, devido a esse fato. Então assim, tudo que eu sei em nível a toques e cantigas foi por estar atenta ao meu redor, mas dentro da religião eu não poderia tocar, não poderia fazer certas coisas que hoje no projeto eu faço. Então assim, é uma religião muito bonita, isso é uma coisa que varia de pessoa para pessoa, mas quando ela tem fé isso agarra. Então isso sempre foi muito bom pra mim, ter esse contato, ter essa vivência, sempre foi muito interessante. Mas é paternalista, então certas coisas você não consegue difundir nem vivenciar dentro do culto. Acabou sendo triste pra mim, descobrir que só os homens tinham acesso, acabou meio que sendo estranho saber que eu, como mulher, não tenho como trabalhar, não tenho como fazer nada a respeito disso. É uma religião bastante antiga, então não existe desconstrução de valores dentro de uma religião, existe uma desconstrução de valores dentro da sociedade, então assim, tem sido muito gratificante pra mim participar desse projeto, porque eu consigo fazer algo que definitivamente eu gosto sem bater de frente com nenhum conceito. Foi a forma que eu encontrei de exercer isso. E eu hoje com 30 anos consigo fazer algo que eu verdadeiramente gosto, porque todas as outras coisas eu fiz porque existia uma necessidade.

Esta entrevistada descreve como, apesar de ter anos de experiência, somente quando se uniu à iniciativa voltada a questões de gênero conseguiu a oportunidade de utilizar o conhecimento que ela havia adquirido através de anos de participação no Candomblé. Práticas, estratégias e metodologias autônomas como as inciativas propostas pelas sujeitas fortalecem a construção de resistência para além de espaços escolarizados. No entanto, suas abordagens interseccionais ressaltam o pensamento decolonial e a pedagogia decolonial nas suas ações.

Segundo Zenzele Isoke (2013) espaços são locais críticos de resistência para mulheres negras. A organização destas inciativas parte da necessidade de um espaço-especificamente um espaço voltado para mulher -, para dialogar sobre questões da mulher, para discutir assuntos referentes a gênero e isto foi levantado nas respostas de algumas das entrevistadas. Por exemplo, uma entrevistada comentou: "Procuro sempre incentivar os cursos por serem um espaço de debate e não existirem outros lugares de debate". 


\title{
norstat 0 \\ Debates Insubmissos
}

Além da relação que estes espaços estabelecem com discussões sobre gênero e questões referentes às mulheres, estes espaços também podem ser entendidos como "espaços políticos", pelo papel que ultimamente representam na organização coletiva. Segundo Isoke (2013), o conceito de espaço político refere-se aos "espaços físicos, simbólicos e relacionais que as mulheres (negras) criam para politizar e transformar comunidades atormentadas por desvantagens econômicas, alienação social e ideologias de gêneroracial altamente destrutíveis que rotineiramente restringem o empoderamento político de seus habitantes" (p. 2). O trabalho de Isoke (op cit) foca-se predominantemente sobre as diversas maneiras que mulheres negras resistem à interseccionalidade estrutural, mas sua conceitualização do conceito de espaço é muito útil para compreender as motivações que levam à construção de espaços designados para mulheres na Maré, trabalhando com uma perspetiva voltada à igualdade de gênero, e ultimamente o rol desses espaços na ação coletiva. Algumas das entrevistadas destacaram especificamente a relação com a necessidade de espaço e questões voltadas especialmente para mulheres, mulheres da periferia. Uma entrevistada forneceu o seguinte comentário:

\begin{abstract}
Algumas amigas e eu percebemos que existiam uma série de violências acontecendo com mulheres próximas a nós aqui na Maré e várias coisas horríveis acontecendo pela cidade com outras mulheres, então vimos a necessidade de ter um espaço de fortalecimento, troca, acolhimento e base de potência entre nós mulheres e que também juntas pudéssemos pensar em como levar debates, reflexões e o combate junto com sexo oposto, como os nossos pais, irmãos, companheiros, amigos e vizinhos. Que fosse um espaço autogestionado e gerido por nós mulheres. Daí a gente percebeu falta de um espaço assim aqui na Maré e a necessidade e importância de ter um. A gente tinha desejos em comum então criamos o Casulo.
\end{abstract}

As mulheres expressaram que a partir da auto-organização, relacionada a uma preocupação com a VCM na sua comunidade, foi possível criar uma identidade política e estabelecer elos de solidariedade. Hurtado (1989 apud Mohanty, 2013a, p.51) na sua discussão sobre o "pessoal é político" enfatiza a relevância da distinção entre o público e privado entre mulheres das elites e mulheres das periferias, mulheres brancas de classe média e alta e mulheres de classe trabalhadora e mulheres de cor que sempre estiveram sujeitas a intervenção do Estado na sua vida doméstica. Hurtado, destacando o papel do estado neoliberal na vida destas mulheres, levanta a seguinte observação: 


\section{sorstat 0 \\ Debates Insubmissos}

Mulheres de cor não têm tido o benefício das condições econômicas que estão subjacentes na distinção entre a distinção público/privado. Por sua vez, a consciência política de mulheres de cor deriva da consciência que o público é pessoalmente político. [...] Não existe uma esfera privada para pessoas de cor exceto o que eles conseguem criar e proteger em um ambiente de outra forma hostil (HURTADO 1989, p. 849 apud MOHANTY, 2013, p.51).

A observação levantada por Hurtado (1989 apud MOHANTY, 2013), e subsequentemente por Mohanty, é significativa quando consideram-se as diferenças que surgem na "política da vida pessoal" de mulheres da periferia em comparação com outras mulheres no Rio de Janeiro, e o papel que estas mesmas assumem na auto organização destas mulheres. $\mathrm{O}$ seguinte trecho de entrevista destaca a noção anteriormente mencionada:

Todo mundo pensa "o Estado não está aqui”, ele não está presente. Na verdade, ele está presente e está determinando como o morador da Maré vai se colocar na sociedade, que vai ser o morador sem qualificação e que vai dar conta desses trabalhos que são mal remunerados, que vão dar conta desses estigmas da sociedade onde coloca a mulher também nesse lugar, porque ele não vai ter outro parâmetro. $\mathrm{O}$ estado está presente manipulando o morador a seguir esse padrão de população pobre, sem acesso e naturalizando isso, fazendo com a que a população naturalize essa "não presença" deles aqui. Então isso está ligado aos grupos civis armados, está ligado à educação, isso está ligado ao não acesso a saúde, é sempre muito tentando naturalizar esses problemas. O grande "Q" do projeto é fazer com que as mulheres se organizem de outra forma e questionem o Estado, questionem a necessidade de direito e essas necessidades de direitos está ligada a várias frentes. Os direitos fundamentais, da constituição de 1988, vai ser do seu direito a ter um trabalho mais digno e isso vai melhorando essa realidade desse território. Só quando a população tem acesso à educação de fato que ela vai refletir de outro jeito essas necessidades aqui e se colocando protagonista dessa transformação e não dando esse papel só para o estado.

Ação e resistência fazem parte destas inciativas e são promovidas nas práticas do pensamento feminista destas mulheres. As práticas e metodologias das inciativas estudadas nesta pesquisa e as percepções das mulheres envolvidas destacam as percepções compartilhadas por elas e a importância da ação coletiva. Estas inciativas estão baseadas na percepção de que a opressão de mulheres não será superada individualmente, mas sim coletivamente e estas inciativas mostram esta perspectiva nas suas formas de se organizar, criar e ensinar. Neste sentido, elas fazem parte das resistências que Mohanty (2013) identifica como inerentes às 
lacunas, fissuras e silêncios das narrativas hegemônicas.A ação de mulheres está assim consagrada nas pequenas práticas do dia a dia e nas lutas (MOHANTY, 2013). Os resultados parecem apontar que as organizações de mulheres são importantes instrumentos de emancipação, principalmente para as mulheres negras e periféricas, pois para estas existem raros espaços em que suas diferentes opressões tenham legitimidade.

\section{DESENVOLVENDO PEDAGOGIAS FEMINISTAS DE BASE COMUNITÁRIA}

Conforme Miguel Arroyo, todas as pedagogias fazem parte dessas relações políticas conflitivas de dominação/reação, libertação (2012). Este estudo percebeu que as mulheres criam pedagogias, através de ações coletivas e ações que dependem do diálogo como estratégia pedagógica que gera reflexão e consciência crítica, em torno da questão de gênero, raça, classe social e outros fatores interseccionais, algumas mais especificamente focadas na mulher na sociedade, em um esforço de abranger as complexidades das experiências femininas da Maré. Elas fazem isto não só através do ensino, mas também no processo de contemplação, decisão da abordagem de temas. Neste sentido, podemos considerar as ações destas mulheres "em movimento", ações dirigidas a construir novas representações sobre a mulher da periferia e sobre Maré em geral. Na linha de Sacramento e Neiva (2011, p.85) a "cartografia teórica de gênero" no universo de mulheres da periferia, dá uma contribuição única à cultura suburbana, já que, tal como os sujeitos subalternizados, essas mulheres passam a ser sujeitas de suas histórias, conduzindo suas vidas, de acordo com valores redescobertos, num contínuo processo de autoconhecimento e transgressão. O seguinte trecho de entrevista exemplifica esta noção de autoconhecimento e transgressão:

Eu penso que o conhecimento é adquirido, mas ela aprendeu que o corpo dela quem manda é ela, elas aprendem a empoderar. Tem a parte do sentimento e a parte do conhecimento. Eu acho que a gente não pode se sentir fracassadas, ou qualquer coisa do tipo, porque mesmo que elas tivessem conhecimento, elas têm o direito das próprias vidas e das próprias escolhas.

Segundo hooks (1999), educar é sempre uma vocação enraizada na esperança. Na perspectiva de Freire (1987), ensinar é um ato político que implica na consciência crítica, a apreciação das experiências vividas, a potência da combinação do diálogo com a ação, 


\section{novist

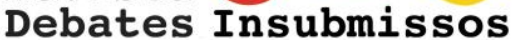

necessidade de desconstruir pensamentos e atitudes eurocêntricas. Questões de justiça e democracia não são distintas de práticas de ensino e aprendizagem. Freire (1987), na sua obra da Pedagogia do Oprimido sublinha o papel da consciência crítica no processo de emancipação da opressão. Conseguir a consciência crítica encoraja indivíduos a afetar a mudança no seu mundo, sociedade e comunidade através da crítica social e ação política. Algo que todas as ações das mulheres têm em comum é a priorização que colocam no diálogo coletivo, na ação coletiva, na criação do pensamento crítico. Desta forma, dialogar, conversar e ensinar se tornam atos políticos. Não se trata de implementar uma forma de pensar ou substituir as ideias já formadas pelos sujeitos, mas sim de fomentar um olhar e um pensar crítico que faça com que considerem outras questões e fatores na formação de suas ideias, neste caso ideias sobre o que significa ser um ser humano, ser uma mulher, pensar sobre as identidades e refletir sobre o papel da mulher na sociedade. Uma entrevistada expressou a seguinte percepção com respeito ao processo de aprendizagem dos participantes:

$\mathrm{Na}$ verdade, a gente coloca na mesa as questões cotidianas e passamos a questionar a mulher ter que assumir diversos papéis. Então ela não naturalizar que o trabalho de casa e o trabalho de fora são da mulher, apenas da mulher. A mulher que é responsável pela educação do filho. A gente passa a questionar todas essas presenças do cotidiano e aos poucos elas começam a se posicionar de outro jeito dentro de casa, e se posicionar de outro jeito dentro de casa passa a influenciar ao marido, que vai ter que se qualificar de outro jeito com ela como esposa ou como mulher e ao próprio filho ou filha que também observa que a mãe acaba se empoderando ou que acaba se colocando de outro jeito e o filho passa a ter uma educação que diminui essa cultura machista que faz parte da cidade, do Brasil.

Outra entrevistada forneceu a seguinte perspectiva com respeito ao processo de aprendizagem das participantes:

Olha, eu acho que o programa de gênero é importante porque talvez coloque alguma luz na cabeça dessas meninas. Às vezes, é o que elas precisam é de alguma coisa que deem um estalo na cabeça delas: "Será que é isso que eu quero pra vida? Eu quero apanhar, estar vivendo numa relação opressiva? Será que eu quero passar dificuldades, passar dificuldades com um filho? É isso que eu quero?" Então é por isso que eu acredito na teoria da mudança que é o que o projeto prega. 


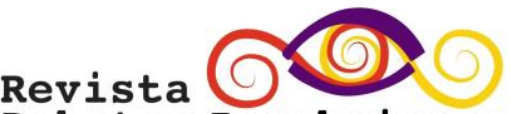 \\ Debates Insubmissos}

Em outras palavras, estas mulheres não propõem a perspectiva de "educá-los, mas como se educam, nem como ensina-lhes, mas como aprendem, nem como socializá-los, mas como se socializam, como se afirmam e se formam como sujeitos sociais, culturais, cognitivos, éticos, políticos que são.” (ARROYO, 2012, p.27).

A ênfase que estas mulheres colocam na relação entre a teoria e a prática em termos de ensinar, enfatiza a noção mencionada anteriormente. Um tema que costumou se repetir nas entrevistas foi o papel específico do ensino superior na transformação da perspectiva de vida e visão do mundo destas mulheres. Destacavam diferentes exemplos de como o acesso ao ensino superior abriu oportunidades, tanto para o próprio indivíduo como para familiares e pessoas próximas. No entanto, a relação entre ensino superior e acesso a oportunidades também foi identificado como um fator que as diferenciam de muitos outros da Maré e da periferia, sendo identificado pelas mulheres que o estudo cumpriu um papel na sua posição e inserção em sua comunidade, bem como the deu melhores condições para criar ações educativas voltadas a questão de gênero, e especificamente ações voltadas para a Maré. Por exemplo, uma entrevistada explicou:

Eu nasci aqui na Maré e diferente de uma realidade comum da maioria dos moradores aqui na Maré, o meu pai teve acesso à universidade. Ele emergiu economicamente e socialmente porque teve essa oportunidade de fazer engenharia...Ele fez um curso, vestibular e passou para engenharia. Ele continua nesse processo de rompimento dessa lógica, porque através dos trabalhos que ele começou a ter acesso, ele fez concurso público para engenharia na prefeitura e é um funcionário público até hoje. A minha mãe terminou o segundo grau somente. Ela não teve acesso à universidade. Ela nasceu aqui na Maré e hoje em dia é uma comerciante daqui. Nesse contexto eu e meus irmãos tivemos acesso à universidade, o meu irmão fez UERJ (odontologia), a minha irmã fez turismo na Estácio e eu fiz gastronomia na Estácio porque era a única universidade que oferecia o curso na época.

Nesse trecho, a entrevistada destaca o papel que teve o ensino superior na vida do pai e na vida dela mesma, sublinhando a relação entre acesso à educação formal e oportunidades. Similarmente, outra entrevistada aponta o papel que teve o acesso a processos educativos, ensino superior, mas destacando como esse acesso a ajudou, como a primeira da família a procurar o caminho para ir à faculdade. Ela descreve sua experiência de vida no seguinte trecho:

E eu acho que o que me fez chegar a graduação de dança foi sim o meu contato com uma ONG, um projeto social que tinha a ligação de todas as áreas 


\section{novstat 0 \\ Debates Insubmissos}

da arte, então nessa ONG, nesse projeto social eu pude entender como seria interessante se a gente pudesse dialogar dança, circo, teatro, música, e isso me fez querer ir pra uma universidade, até então eu nunca tinha pensando que poderia estar. Até porque eu venho de família que nunca ninguém se formou, nunca ninguém teve graduação, então nunca soube direito como seria chegar em um caminho desse. Foi apenas dos projetos sociais que participei que eu pude enxergar um além de acreditar na arte e ver que através disso a gente pode mudar alguma coisa na sociedade.

O acesso à educação descrito pelas entrevistadas evidencia como o entendimento de si próprio e de outros pode adaptar e transformar suas concepções de si própria e do mundorealidade em que habita. Neste sentido, do território e de suas dinâmicas por meio de reflexões teóricas somadas ao processo de autoconhecimento/autoidentificação como ser, como mulher, como sujeito histórico. A questão de identidade também é ressaltada por mulheres entrevistadas sobre o papel de cotas e o acesso ao ensino superior. Uma mulher entrevistada comentou:

Ainda mais dentro do tempo que a gente vive, de tantos retrocessos
educacionais a gente tem vivido retrocessos e eu tô aqui pra afirmar o quanto
importante foram as cotas das universidades, o quanto importante são as
bolsas universitárias oriundas de alunos de espaços populares, alunos negros, o
quanto isso fez diferença na minha vida, porque se não fossem as cotas,
dificilmente a gente estaria em uma universidade.

A maioria das entrevistadas tinha completado ensino superior ou estavam cursando ensino superior. Algumas haviam tido alguma aproximação com teoria crítica feminista e afirmavam isto. Embora destaquem que, apesar de estarem na faculdade, seu contato com a teoria crítica de feminismo ou o tema de gênero foi limitado. Por exemplo, uma entrevistada descreveu a sua experiência na faculdade com a teoria crítica feminista:

O pouco que eu debati sobre gênero, foi quando eu fazia parte do centro acadêmico de ciências sociais da UERJ, que a gente organizava os estudantes e na época que eu militava PSTU como partido, que ai a gente tinha o CONLUTAS (Comitê Nacional de Lutas), que era um sindicato, que era como se fosse uma cisão da CUT, que é a central única sindical e a CONLUTAS é um outro sindicato de trabalhadores que não envolve só trabalhadores, como estudantes. Dentro da CONLUTAS tinha as divisões, tinha o pessoal do LGBT, tinha o pessoal de Mulheres, então tinha o Movimento de Mulheres da CONLUTAS. Eu participava do Movimento de Mulheres da CONLUTA porque eu era do partido, foi aonde eu tive a proximidade, que eu fui pra congresso em São Paulo, que a gente participou de eventos, que a delegação 


\section{norstat 0 \\ Debates Insubmissos}

votava quais eram as diretrizes, quais eram as lutas que a gente ia passar aquele ano.

Outra entrevistada expressou o seguinte com respeito à sua experiência com os temas de gênero e feminismo na faculdade:

Fiz disciplinas na faculdade, mas um curso específico de gênero nunca fiz. Fiz só coisas pontuais, fiz um curso de extensão, direitos sexuais e reprodutivos, na pós-graduação trabalhamos a questão de gênero e sexualidade, mas foi módulo, na própria faculdade houve disciplina de gênero, mas curso específico nunca fiz não.

A maioria das entrevistadas destacou o processo do educador que aprende junto com seus alunos. Enfatizaram muito a importância da teoria associada à prática, particularmente apontando a inerente dependência entre os dois para a construção de uma práxis atenta ao mundo-realidade dos educandos. Uma entrevistada comentou o seguinte sobre o papel da prática no ensino focado em questões de gênero:

É sempre um aprendizado, não só com a equipe, mas quando aplicamos a atividade, as vezes nós temos só a experiência teórica enquanto os alunos têm na prática, então é uma troca bem positiva. É fácil falar de um tema quando você domina teoricamente, mas é complicado você abordar esse tema quando se vive na prática, essa troca acaba complementando nosso trabalho.

Conforme a análise de Arroyo sobre a contribuição da teoria de educação de Paulo Freire é apontada a necessidade de:

Destacar que os próprios oprimidos têm suas pedagogias de conscientização da opressão e dos processos de desumanização a que são submetidos já aponta que eles afirmam outras pedagogias em tensão com as pedagogias de sua desumanização que roubam sua humanidade. Por outro lado, ao reconhecer suas pedagogias reconhece que os oprimidos são sujeitos pedagógicos não destinatários de pedagogias de fora, nem sequer críticas progressistas, conscientizadoras e menos bancárias. A diversidade de coletivos, sujeitos em ações e movimentos radicalizam e repolitizam a Pedagogia do Oprimido em pedagogias de emancipação em movimento (2012, p. 28).

Neste sentido, as pedagogias desenvolvidas por estas mulheres funcionam de acordo com o que Arroyo (2012) afirma em relação ao fato dos movimentos sociais coletivos na educação apontarem que as teorias pedagógicas não são estáticas, mas participam dos tensos processos históricos de humanização/emancipação, de reação à desumanização/subordinação. Ensinar como ato político pode fazer que se manifestem novas perspectivas sobre identidade, 
experiência e formas de conhecimento. É uma forma de reescrever a história, mobilizar para um futuro e desfazer estereótipos prejudiciais. O seguinte trecho de entrevista representa o pensamento de umas das entrevistadas conforme o papel da inciativa na Maré, "Desmistificar os valores que são construídos na sociedade, repensar o nosso lugar e qual o nosso papel na sociedade".

Os métodos implementados pelas mulheres entrevistadas fundamentam-se no diálogo, discussão coletiva que pode cumprir um papel na fomentação de consciência crítica e a transformação social. Assim as mulheres criam espaços, que consistem em lugares para compartilhar histórias e debater questões de gêneros, que a partir das perspectivas delas são necessários e imprescindíveis para a reconstrução de identidades, pensamentos, subjetividades.

\section{CONSIDERAÇÕES FINAIS}

A categoria mulher para estas sujeitas entrevistadas implica em diversidade e pluralismo, mostrando que diferentes fatores precisam ser considerados quando pensamos no lugar da mulher na sociedade brasileira. Suas ações apoiam-se na pedagogia crítica, que envolve processos de desaprender, reaprender, pensar e agir. Através de suas ações educativas e coletivas, as mulheres entrevistadas afirmam sua presença e as distinções que caracterizam as vidas de mulheres na periferia que precisam ser levadas em conta quando trabalhando questões relacionadas à igualdade de gênero e os feminismos. Em parte, a experiência das mulheres entrevistadas, junto com as características de cada iniciativa destaca a observação compartilhada por todas da necessidade de outras pedagogias, outros saberes, além de outras maneiras de trabalhar questões de gênero e feminismo com mulheres da periferia. As pedagogias criativas destas mulheres permitiram uma compreensão mais aprofundada sobre a contínua realidade vivida por estas comunidades com respeito ao poder colonial, dominação e racialização. Assim, considero que tais iniciativas de Feminismo de Base Comunitária se aproximam de uma perspectiva freireana de Educação Critica e Transformadora (1994) que pretende transformar, de forma especifica, a VDG e VCM, entendidas, neste caso, como Situações-limites que precisam ser transformadas em nome da melhoria das condições de vida destas comunidades. 
O feminismo decolonial e o pós-colonial foram duas das diretrizes epistemológicas utilizadas neste artigo. O feminismo pós-colonial destaca a necessidade de apontar as lacunas que surgem quando a categoria de mulher é fundamentada em noções de universalização. Feministas pós-coloniais destacam a complexidade e as fraturas nas maneiras de conceber gênero e sexualidade a partir do feminismo ocidental e como estas são categorias centrais para a questões de nacionalismo, colonialismo e racismo. A perspectiva decolonial apresenta um caminho de luta contínua e persistente que objetiva visibilizar e incentivar a construção de categorias representativas das vidas, realidades, pensamentos e "re-existencias" das mulheres do sul global.

Sobre as estratégias de enfrentamento e combate à Discriminação de Gênero, entendo que, somente as ações classificadas como transformadoras e decoloniais poderiam ser enquadradas como produtos de uma perspectiva de Feminismo de Base Comunitária, considerando que esta abordagem propõe a superação de uma Situação-Limite a partir de um Ato-Limite, ou seja, uma ação transformadora capaz de alterar uma condição naturalizada de opressão-invisibilização-subalternização que, neste caso, assume uma influência da colonialidade e das lutas de classes presentes na América Latina. Portanto, entendo que uma perspectiva de Feminismo de Base Comunitária desenvolvida com comunidades das periferias da América Latina, deve considerar, por levar em conta as especificidades históricas deste território, não apenas a dimensão da luta de classes, mas também a dimensão da decolonialidade, por entender que a própria divisão de classes neste contexto é perpassada pelos reflexos da colonização.

Com relação a algumas questões respondidas por este trabalho, destaco, em primeiro lugar, o que tais experiências podem informar sobre a Educação de Gênero em contexto de periferia urbana no Rio de Janeiro que, neste caso, destaca a inexistência/insuficiência de espaços formais para realizar discussões de gênero, bem como ressalta que este debate é entendido por tais mulheres como um tema relevante para suas vidas. Do mesmo modo, as falas de tais mulheres evidenciaram a existência de um abismo entre as teorias acadêmicas feministas e as práticas produzidas nos territórios, o que reforça a necessidade de se integrar a teoria à prática, no sentido de produzir uma práxis feminista atenta a necessidade de produzir ações, conhecimentos e práticas contextualizadas às especificidades dos territórios e identidades locais. 
Ainda neste sentido, destaca-se que determinados pontos da teoria acadêmica feminista foram empregados para fundamentar determinadas ações destas iniciativas.

\section{REFERÊNCIAS}

ALVAREZ, Sônia; DAGNINO, Eevelina; ESCOBAR, Arturo. Cultura e política nos movimentos sociais latino-americanos: novas leituras. Belo Horizonte: Ed. UFMG, 2000. ARROYO, Miguel. Outros Sujeitos, Outras Pedagogias. Petropolis, Rio de Janeiro, Editora Vozes, 2012.

BALLESTRIN, Luciana. América Latina e o giro decolonial. Revista Brasileira de Ciências Políticas, V.11, p. 89-117, 2013.

BARDIN, Laurence. Analise de Conteúdo. São Paulo, Edições 70, 2011.

BARTHOLL, Timo. Territórios de resistência e movimentos sociais de base: uma investigação militante em favelas cariocas. 452 f. Tese (Doutorado em Geografia), Universidade Federal Fluminense, Niterói/Rio de Janeiro, 2016.

BISPO, Antônio. Colonização e Quilombos: modos e significados. Universidade de Brasília UnB, Brasília, 2015.

BRANDÃO. Carlos Rodrigues. O que é Educação Popular. São Paulo: Brasiliense, 2007.

CARLOS, Euzeneia. Movimentos sociais e instituições participativas: Efeitos do engajamento institucional nos padrões de ação coletiva. Revista brasileira de ciências sociais, v. 30, n. 88, p. 83-98, 2015.

CARVALHO, Monique Batista. Uma Maré de Lutas: Memória e Mobilização Popular na Favela Nova Holanda - RJ (dissertação de Mestrado). Universidade Federal do Estado do Rio de Janeiro (UNIRIO). Programa de Pós-Graduação em Memória Social, 2006.

COSTA, Claudia de Lima. Feminismo e Tradução Cultural: Sobre a Colonialidade de Gênero e a Descolonização do Saber. Portuguese Cultural Studies, p. 41-65, 2012.

COSTA, Milena; SERAFIM, Marcia; NASCIMENTO, Aissa. Violência contra a Mulher: Descrição das Denúncias num centro de referência de atendimento à Mulher de Cajazeiras, Paraíba, 2010-2012. Epidemio.ser.saude, Brasília, v. 24, nº 3, p. 551-558, 2015.

CRENSHAW, Kimberlé. "Mapping the Margins: Intersectionality, Identity Politics, and Violence Against Women of Color." Stanford Law Review 43 (6): 1241-99, 1991. 
CURIEL, Ochy. La descolonización desde una propuesta feminista crítica. In: Feminista Siempre: Descolonización y despatriarcalización de y desde los feminismos de Abya Yala. ACSUR-LAS SEGOVIAS, p. 11-22, 2015

DINIZ, E.; BELFORT, M.; RIBEIRO, P. Memória e Identidade dos Moradores de Nova Holanda. Redes De Desenvolvimento da Maré: Rio de Janeiro, 2012.

DUSSELL, Enrique. 2491: O Encobrimento do Outro - A Origem do Mito da Modernidade (Tradução Jaime A. Clasen) - Petrópolis, Rio de Janeiro. Vozes, 1993.

ESPINOSA, Yuderkys. Etnocentrismo y colonialidad en los feminismos latinoamericanos: Complicidades y consolidación de las hegemonías feministas en el espacio transnacional.Feminismo latinoamericano, Revista Venezolana de Estudios de la Mujer, Vol. $14 \mathrm{~N}^{\mathrm{o}} 33 \mathrm{jul} / \mathrm{dic} 2009$.

FRANCO, Marielle. UPP - A Redução da Favela a três letras: Uma análise da política de segurança pública do estado do Rio de Janeiro (dissertação de mestrado). Universidade Federal Fluminense. Programa de Pós-graduação em Administração, Rio de Janeiro, 2014.

FREIRE, Paulo. Educação e Mudança. $5^{\text {a }}$ Ed, Paz e Terra, 1982.

Pedagogia do oprimido. $17^{\mathrm{a}}$ Ed, Rio de Janeiro, Paz e Terra, 1987.

HOOKS, bell. On Self Recovery, In HOOKs, Bell:Talking Back: Thinking Feminist, Thinking Black. Boston, MA: South End Press, 1999.

HURTADO, Aida. Relating to Privilege: Seduction and Rejection in the subordination of white women and women of color. Signs, 14, n4, p.833-855, 1989.

ISOKE, Zenzele. Urban Black Women and the Politics of Resistance. New York: Palgrave Macmillan, 2013.

KOROL, Claudia. La educación como práctica de la libertad: Nuevas lecturas posibles. In: . Hacia una pedagogía feminista: géneros y educación popular pañuelos en Rebeldía.

Buenos Aires: Editorial El Colectivo: América Libre, p.9-22, 2007.

LAGE, Allene. Orientação epistemológica para pesquisa qualitativa em educação e movimentos sociais. Anais do IV Colóquio Internacional de Políticas e Práticas Curriculares: Diferenças nas Políticas de Currículo. João Pessoa: UFPB, 2009.

LUGONES, María. Rumo a um feminismo descolonial. Estudos Feministas, Florianópolis, v. 22, n. 3, p. 935-952, jan. 2014. 
MALDONATO-TORRES, Nelson. Sobre La colonialidad Del ser: contribuiciones al desarollo de um concepto. In: CASTRO-GOMEZ, S.; GROSFOGUEL, R (Orgs). El Giro Decolonial. Reflexiones para una diversidad epistêmica más Allá Del capitalismo global. Bogotá: Universidad Javeriana - Instituto Pensar, Universidad Central - IESCO, Siglo Del Hombre Editores, p 127-167, 2007.

A topologia do ser e a geopolítica do conhecimento - modernidade, império e colonialidade. In: SANTOS, Boaventura de Sousa; MENESES, Maria Paula. Epistemologias do Sul. São Paulo: Cortez, 2010.

MIGNOLO, Walter. El Pensamiento Decolonial: Deprendimeiento y apertura. Um manifesto. In: CASTRO GOMES, Santiago., Gosfoguel, Ramon (Orgs). El Giro Decolonial: Reflexiones para uma diversidade epistêmica mas aya del capitalismo global. Siglo del Hombre Editores, Instituto Pensar, 2007.

MOTTA-NETO, João Colares da. Educação Popular e Pensamento Decolonial latinoamericano em Paulo Freire e Orlando Fals Borda (tese de doutorado). Universidade Federal do Pará, Instituto de Ciências da Educação, Programa de Pós-graduação em Educação, Belém, 2015.

MURACA, Maria Teresa. Praticas pedagógicas populares, feministas e decoloniais do movimento de mulheres camponesas em santa catarina. 2015. 402f. Tese (Doutorado em Ciências Humanas) Programa de Pós-graduação Interdisciplinar em Ciências Humanas da Universidade Federal de Santa Catarina, Florianópolis, 2015.

NASCIMENTO, Marcos. Masculinidade, juventude e violência contra mulher: articulando saberes, práticas e políticas. In: BLAY, Eva Alterman. Feminismos e masculinidades: novos caminhos para enfrentar a violência contra mulher. São Paulo: Cultura académica, p.21-225, 2014.

NASCIMENTO, M. \& SEGUNDO, M. Hombres. Masculinidades y políticas públicas: aportes para la equidad de género. In: AGUAYO, Francisco; SADLER, Michelle. Masculinidades y políticas públicas: involucrando a los hombres en la equidad de género. Santiago: Universidad de Chile, p.50-62, 2011.

PITANGUY, Jaqueline. Advocacy e Direitos Humanos. In: PITANGUY, Jaqueline \& BARSTED, Leila. O Progresso das Mulheres 2003-2010. Rio de Janeiro, Sepia/ONU Mulheres, 2011.

PORTO GONÇALVES, Carlos Walter. Apresentação da Edição em Português. In: LANDER, Edgard (org). A Colonialidade do Saber: eurocentrismo e ciências Sociais perspectivas latinoamericanas. Coleccíon Sur Sur, CLACSO, 2005. 
MOHANTY, Chandra. Transnational Feminist Crossings: On Neoliberalism and Radical Critique.Signs: Journal of Women in Culture and Society: Chicago Press, vol. 38, no. 4, p.967991, 2013.

Feminism without Boarders: Decolonizing Theory, Practicing Solidarity. North Carolina: Duke University Press, 2003.

MOHANTY, Chandra \& MARTIN, Biddy. Whats Home Got to do With It. In: Feminism without Boarders: Decolonizing Theory, Practicing Solidarity. North Carolina: Duke University Press, 2003.

QUIJANO, Aníbal. Colonialidade do poder e classificação social. In: SANTOS, Boaventura Sousa; MENESES, Maria Paula. Epistomologias do Sul. São Paulo: Cortez, 2010.

RIVERA, Patricia Elisa. Feminismo de Base Comunitária em Contexto de Periferia Urbana: Iniciativas que discutem questões de gênero na Maré (RJ) (tese de doutorado). Universidade do Estado do Rio de Janeiro, Rio de Janeiro, 2017.

SACRAMENTO, Maria $\mathrm{P}$, \& NEIVA, Luciano S. Mulheres da periferia: feminismo e transgressão em Guerreira de Alessandro Buzo. IPOTESI, JUIZ DE FORA, v.15, n.2 Especial, p. 81-92, jul./dez. 2011.

SANDELL, Renee. The Liberating relevance of Feminist Pedagogy.Studies in Art Education, Vol.32, No. 3, p. 178-187, 1991.

SPIVAK, Gayatri Chakravorty. Pode o Subalterno Falar? (tradução de Sandra Regina Goulart de Almeida; Marcos Pereira Feitosa; André Pereira Feitosa). Editora UFMG, 2010.

WALSH, Catherine. Lo Pedagogico y lo Decolonial entretejiendo caminos. In: WALSH, Catherine (Ed). Pedagogias Decoloniales praticas insurgentes de resistir, (re)existir y (re)vivir. Tomo I, Ed Abya Yala, Quito, Equador, 2010.

ZIBECHI, Raúl. Territórios em Resistência: Cartografia política das periferias urbanas latino-americanas. Rio de Janeiro: Consequência, 2015.

Submetido em:01/07/2018

Aprovado em: 24/08/2018 